\title{
VARYING CONTRACTS IN THE SUPREME COURT
}

ROCK Advertising Ltd. v MWB Business Exchange Centres Ltd. [2018] UKSC 24

raised two fundamental issues in the law of contract. First, can an oral variation be effective in the face of a no-oral modification ("NOM") clause? Secondly, is part payment of a debt good consideration for satisfaction of the debt? The majority of the Supreme Court answered "No" to the first question, overturning the Court of Appeal (noted [2016] C.L.J. 455). None of the Justices felt it necessary or appropriate to answer the second question. It is suggested that both questions should have been dealt with differently.

Rock occupied as licensee premises managed by MWB. Rock decided to expand, and entered into a written agreement with MWB for larger premises for 12 months beginning 1 November 2011 . The agreed licence fee was $£ 3,500$ per month for the first three months, and $£ 4,433.34$ subsequently. Rock’s business was not successful, and by February 2012 it had incurred arrears of over $£ 12,000$. The parties orally agreed to re-schedule the licence fee payments due from February to October 2012: Rock would pay less for the first few months, and more subsequently, so the arrears would be cleared by the end of the year. Nevertheless, MWB later sought to enforce the original terms of the agreement and sued for the arrears.

Clause 7.6 in the original contract stated: "All variations to this licence must be agreed, set out in writing and signed on behalf of both parties before they take effect." Lord Sumption, with whom Lady Hale, Lord Wilson and Lord Lloyd-Jones agreed, held that this clause was legally effective. Therefore the purported oral variation of the contract could not be enforced. Lord Sumption observed that NOM clauses prevent attempts to undermine written agreements by informal means; avoid disputes about whether a variation was intended and what its terms were; and make it easier for corporations to police internal rules restricting individuals' authority to agree to contractual variations. These are pragmatic justifications that may reflect parties' legitimate commercial reasons for inserting NOM clauses (see Morgan [2017] C.L.J. 589).

However, this approach of the Supreme Court towards NOM clauses represents a significant departure from that of other common law jurisdictions. This might be contrasted with other statements from the Supreme Court favouring harmonisation throughout the common law world (see e.g. FHR European Ventures 
LLP v Cedar Capital Partners LLC [2014] UKSC 45, [2015] A.C. 250, at [45]). The traditional approach of the common law has been encapsulated in the observation of Cardozo J. in Alfred C Beatty v Guggenheim Exploration Company (1919) 225 N.Y. 380, 387: "Those who make a contract, may unmake it. The clause which forbids a change, may be changed like any other. The prohibition of oral waiver, may itself be waived. ... Whenever two men contract, no limitation self-imposed can destroy their power to contract again ..."

Lord Sumption thought objections to his preferred approach to be "entirely conceptual" (at [13]). But that does not render them any less persuasive. Conceptual clarity is important. Parties are free to enter into contracts, without (generally) any requirements of form. If the parties intend to be bound, and consideration is provided to support the promises made, then a contract arises. The same should be true of variation. Just as Parliament cannot bind its successors, nor should a contract prevent future contracts. The conceptual point can be reinforced by querying where the limits of $M W B$ lie: can a clause prevent any variation at all? Or novation? Or waiver? If so, the restriction an earlier term puts on the parties' later freedom of contract is stark and, it is suggested, unfortunate. It may be that the decision is restricted to NOM clauses for pragmatic reasons, but in the face of conceptual difficulties the limits of the decision in $M W B$ are likely to come under sustained pressure.

Lord Sumption bolstered his decision by drawing an analogy with entire agreement clauses. But those clauses preclude reliance upon earlier understandings or agreements between the parties, such that the latest agreement (containing the entire agreement clause) prevails. NOM clauses have the opposite effect: the most recent agreement of the parties is not enforced, but the earlier agreement (containing the NOM clause) preferred. It is suggested that the most recent agreement of the parties should be enforced. Lord Sumption's assertion that enforcing the most recent agreement "override[s] the parties' intentions" (at [11]) is therefore contestable: viewed from the perspective of what the parties intended at the date of the variation (rather than the original contract date), the opposite is true.

Lord Briggs' approach was more nuanced than that of the majority. He thought that an oral variation may be effective, provided the parties agree expressly or by necessary implication to dispense with the NOM clause. This is preferable to the bold approach of the majority, but still unnecessarily restrictive. Where parties have 
reached an agreement that is supported by consideration, courts should give effect to that agreement. If it varies an earlier contract, so be it. The last in time should prevail.

In following the Supreme Court's approach, it is likely that increased attention will be given to doctrines such as estoppel, which provide some protection against the strict enforcement of NOM clauses. But Lord Sumption was keen to stress (at [16]) that "the scope of estoppel cannot be so broad as to destroy the whole advantage of certainty" sought from NOM clauses. Nevertheless, it is to be expected that many disputes will focus upon estoppel: what will need to be established for the defence of estoppel to succeed? Will an estoppel have only suspensory effect?

On the facts of $M W B$ all the Justices agreed that the oral variation was ineffective. This made it unnecessary to discuss the doctrine of consideration. Yet the law in this area is riddled with difficulties. In Foakes v Beer (1884) 9 App. Cas. 605 the House of Lords held that part payment of a debt was not good consideration for the extinguishment of the debt. But, as Lord Sumption recognised, the more recent approach of the Court of Appeal in Williams v Roffey Bros \& Nicholls (Contractors) Ltd. [1991] 1 Q.B. 1 is difficult to reconcile with Foakes. In Roffey, the court found that a promise to pay more might be supported by consideration if the promisor “obtains in practice a benefit or obviates a disbenefit" ([1991] 1 Q.B. 1 at 16). In In re Selectmove Ltd. [1995] 1 W.L.R. 474 the Court of Appeal did not extend such reasoning to part-payment of a debt. But the Court of Appeal in $M W B$ appeared to differ from Selectmove and apply Roffey instead of Foakes in the context of partpayment.

The reluctance of the Supreme Court to grapple with this issue of consideration is understandable. If the court had split in obiter dicta, additional confusion may have resulted. But as Lord Sumption acknowledged at the very start of his judgment, "[m]odern litigation rarely raises truly fundamental issues in the law of contract" (at [1]). It is perhaps unlikely that the Supreme Court will soon be presented with the opportunity to revisit this issue. Lord Sumption's unsurprising recognition (at [18]) that Foakes "is probably ripe for re-examination" may provide some encouragement to parties to take the point to the Supreme Court, but that is an expensive process with an uncertain outcome; both Roffey and Selectmove settled before being heard by the House of Lords.

It is suggested that it is unfortunate that their Lordships side-stepped consideration, especially because the issue had been fully argued. The Supreme Court 
often deals with points not necessary for the outcome of the case (e.g. In the matter of an application by the Northern Ireland Human Rights Commission for Judicial Review (Northern Ireland) [2018] UKSC 27, [2018] H.R.L.R. 14), and sometimes even signals a departure from earlier House of Lords' authority in obiter dicta (e.g. Ivey v Genting Casinos UK Ltd. [2017] UKSC 67, [2017] 3 W.L.R. 1212). Lord Sumption thought "an enlarged panel of the court" would be needed, but this may not have been any more helpful (see e.g. Burrows (2013) 127 L.Q.R. 305, 307-309) and is not invariably necessary to depart from earlier decisions of the House of Lords (e.g. Ivey). Moreover, the size of the panel is determined by the Supreme Court itself; it is odd that it did not decide to sit in an enlarged panel if this would have been important had the issue of NOM clauses been decided differently.

In the wake of the Supreme Court decision in $M W B$, Kerr J. has reiterated, albeit with some reluctance, the orthodox view that a "practical benefit" does not constitute good consideration for payment of part of an existing debt, since Selectmove remains binding (Simantob v Shavleyan (t/a Yacob's Gallery) [2018] EWHC 2005 (QB) at [119]-[138]). That approach is most consistent with Foakes. Yet in $M W B$ the Court of Appeal held that MWB did receive consideration for accepting a less advantageous schedule of payments: MWB would ultimately be likely to recover a greater sum through the rescheduling of payments, and, importantly, MWB would avoid the property standing empty for some time, causing further loss. Lord Sumption recognised that " $[\mathrm{t}]$ hese were both expectations of practical value, but neither was a contractual entitlement" (at [18]). In Simantob, Kerr J. did not consider the tension between the decisions of the Court of Appeal in Selectmove and MWB. But since the Supreme Court in $M W B$ did not overturn the Court of Appeal on the issue of consideration, the decision of the latter is likely to continue to prove troublesome. The law on consideration in the context of variation remains in a mess.

PAUL S. DAVIES

Address for Correspondence: UCL Faculty of Laws, Bentham House, 4-8 Endsleigh Gardens, London, WC1H 0EG 